\title{
Pemberdayaan Remaja Muslim melalui Program Akademi Berdaya Kreatif
}

\author{
Jamaludin Al Afgani* \\ Jurusan Pengembangan Masyarakat Islam, UIN Sunan Gunung Djati, Bandung \\ *Email:jamalafgan77@gmail.com
}

\begin{abstract}
The purpose of this research is to find out methods in community empowerment that are in accordance with the object of adolescents, as well as processes and programs that are useful for youth empowerment carried out by the Creative Empowerment Foundation through empowered academy programs. This study uses a descriptive method with a type of data that is qualitative which describes and explains the facts in the field, using data collection techniques, interviews and documentation studies. The results of the first study, the youth empowerment process carried out by the Creative Empowerment Foundation through a empowered academy program by inviting the community to become volunteers and foster brothers and sisters then looking for and providing understanding of theories that are relevant to teenagers' desires, whose targets are orphaned teenagers. Second, methods of empowering education and practices that are in accordance with the moral curriculum. Third, a movement to improve the quality and capacity of institutions by providing training to volunteers and carers and administrators to remember about empowering and being sincere in empowering.
\end{abstract}

Keywords:Empowerment; Academy; Creative.

\begin{abstract}
ABSTRAK
Tujuan dari penelitian ini dilakukan untuk mengetahui metode dalam pemberdayaan masyarakat yang sesuai dengan objeknya yakni remaja, serta proses dan program yang bermanfaat bagi pemberdayaan remaja yang dilakukan oleh Yayasan Berdaya Kreatif melalui program akademi berdaya.Penelitian ini menggunakan metode deskriptif dengan jenis data kualitatif yang menggambarka dan menjelaskan fakta-fakta di lapangan, dengan teknik pengumpulan data melalui observasi, wawancara dan studi dokumentasi.Hasil penelitian diperoleh bahwa pertama, proses pemberdayaan remaja yang dilakukan oleh Yayasan Berdaya Kreatif melalui program akademi berdaya dengan mengajak masyarakat untuk menjadi relawan dan kakak asuh kemudian mencari dan memberikan pemahaman tentang teori yang relevan dengan keingin remaja, yang sasarannya adalah remaja yatim dhuafa. Kedua, metode pemberdayaan pendidikan dan
\end{abstract}




\section{J. Al Afgani}

praktik yang sesuai dengan kurikulum berakhlaq. Ketiga, gerakan untuk meningkatkan kualitas dan kapasitas lembaga dengan memberi pelatihan pada relawan dan kakak asuh serta pengurus untuk ingat tentang memberdayakan dan ikhlas dalam memberdayakan.

Kata Kunci : Pemberdayaan; Akademi; Kreatif.

\section{PENDAHULUAN}

Remaja pada saat ini sudah mulai melupakan jati dirinya, terbukti dengan banyak beredarnya remaja yang lebih mementingkan menjadi pengikut dalam suatu media sosial dengan melakukan tindakan bodoh. Hal ini terjadi karena remaja merupakan masa peralihan di antara masa anak-anak dan masa dewasa di mana anak-anak mengalami pengaruh luar biasa di segala bidang.

Masa peralihan ini lah yang akan menjadikan remaja melihat bagaimana dirinya ketika dewasa nanti, perkembangan remaja hari ini cenderung terlalu cepat, sehingga ada pemendekan masa muda menuju dewasa khususnya di belahan bumi selatan. Tyska berpendapat bahwa anak muda di dunia Barat sedang mengalami perpanjangan masa muda karena anak-anak muda sekarang cenderung menghabiskan waktu yang lebih lama untuk mengenyam pendidikan formal, memiliki pekerjaan paruh waktu, dan masih tergantung pada orang tua. Di sisi lain, anak muda di belahan bumi selatan mengalami periode masa muda yang diperpendek karena banyak yang harus menjadi pekerja anak, terkurung dalam kemiskinan dan memiliki kesempatan pendidikan yang terbatas. Mengindikasikan bahwa kekurangan dalam hal pendidikan dapat membuat seseorang lebih cepat dewasa dan membuang masa muda nya.(Faturochman, 2012: 119-120)

Tentunya hal ini akan menjadi seuatu permasalah besar, apabila dihubungkan dengan Negara Indonesia yang sebentar lagi akan menghadapi bonus demografi di 2020-2030, di mana jumlah penduduk usia produktif yang sangat banyak. Bonus Demografi atau sering juga di sebut keuntungan demografi merupakan fase di mana jumlah penduduk produktif (15-64 tahun) jauh lebih besar dibandingkan jumlah penduduk tidak produktif (0-14 dan 65 tahun ke atas). Jika dihubungkan dengan pendapat Tyska tentang pemendekan masa muda yang seharusnya mendapatkan pendidikan lebih banyak, maka di pandang perlu jika remaja mendapatkan suatu bimbingan untuk berdaya. Karena, suatu keharusan untuk dapat membantu remaja menemukan apa yang di inginkan oleh mereka di masa depan.

Permasalahan yang menjadi konteks utama dari masyarakat adalah keinginan mereka untuk berubah, memilih untuk lebih modern dan terbuka pada perubahan, masyarakat yang ada di Indonesia khususnya di daerah-daerah tidak sedikit yang masih menolak suatu pembaharuan, kemudian kurangnya 
pendidikan yang masuk terhadap mereka yang menimbulkan suatu permasalahan yang lebih dalam, seperti semakin banyak masyarakat buta huruf, kemudian usia muda yang di tuntut untuk dewasa lebih cepat, dan meninggalkan masa remajanya hanya untuk bekerja tanpa mengetahui bahwa ada yang lebih dalam kehidupan.

Masa remaja adalah masa yang penuh dengan tantangan untuk melatih kemampuan diri dalam menyelesaikan permasalahan-permasalahan yang terjadi dalam kehidupan secara nyata dan mengembangkan karakter yang ada pada dirinya. Karakter adalah totalitas atribut individual dan ciri sifat kepribadian, meliputi ciri moral, social dan sikap religiositas. Maka dalam membantu hal tersebut di perlukan ada perhatian dan bimbingan untuk mencapai hasil yang diinginkan dalam mencapai kedewasaan. Perkembangan menuju kedewasaan memerlukan perhatian kaum pendidik secara bersungguh-sungguh. Dalam hal ini tentunya tidak hanya peran dari sekolah tapi dari semua pihak yang berhubungan langsung agar dapat membimbing dan memperhatikan perkembangan remaja khususnya karakter mereka. (Faturochman, 2012:138)

Perkembangan karakter merupakan pengembangan yang bertahap dalam membentuk sikap, mental dan akhlak. Membangun karakter adalah proses mengukir jiwa, sehingga terbentuk jiwa yang unik, menarik dan lain daripada yang lain. Dalam perkembangan karakter ini hal yang akan menjadi factor utama adalah lingkungan, pengalaman dan bimbingan dari pendidik. Tentunya dengan terbentuknya karakter yang positif dapat membantu para remaja dalam mensejahterakan diri yang nantinya dapat direalisasikan pada kehidupan untuk bertahan hidup dan bersikap tenang dalam menyelesaikan permasalahan yang ada. (Faturochman, 2012: 138)

Perkembangan karakter dari masa muda menuju dewasa dapat menghasilkan pemikiran yang lebih dewasa atau prinsip pendidikan orang dewasa. Menurut Lindeman menggambarkan karakteristik pembelajar dewasa sebagai berikut : (1) orang dewasa termotivasi untuk belajar bila terkait dengan kebutuhan dan ketertarikan pribadinya; (2) orientasi orang dewasa untuk belajar adalah berpusat pada kehidupan; (3) pengalaman merupakan sumber belajar yang kaya bagi pembelajar dewasa; (4) orang dewasa memiliki kebutuhan mendalam untuk mengarahkan diri sendiri; dan (5) perbedaan antar-individu meningkat berdasarkan bertambahnya usia. Berdasarkan karakteristik tersebut maka proses pembelajaran yang cocok adalah pemberdayaan masyarakat, berbasis keahlian hidup dan memberdayakan diri dan masyarakat yang lain (Faturochman, 2012:139).

Hal ini menjadi salah satu kegiatan yang sangat baik yang dilakukan oleh suatu yayasan bernama Yayasan Berdaya Kreatif di daerah Kabupaten Garut yang begerak di bidang pemberdayaan masyarakat, di mana dari program- 


\section{J. Al Afgani}

program yang ada di yayasan tersebut mendukung gerakan Indonesia berdaya, membantu masyarakat daerah dalam menemukan potensi yang ada pada diri dan alam mereka. Tidak hanya itu yayasan ini juga membantu masyarakat yang dikategorikan tidak mampu di daerah yang menjadi daerah binaan yayasan tersebut, juga membantu korban terdampak banjir bandang di Garut serta bekerja sama dengan panti-panti asuhan untuk membentuk remaja yang berkemanuan untuk berkembang dan memperoleh apa yang mereka inginkan.

Maka dari hal itu akan menemui hasil yang positif jika terdapat peningkatan sumber daya manusia untuk membantu terciptanya masyarakat yang sejahtera dan juga siap terjun dalam membangun bangsa, tentunya apa yang diharapkan dari adanya bonus demografi tahun 2020-2030 dengan banyaknya usia produktif dapat meningkatkan kesiapan para remaja dalam menghadapi permasalahan baik dari kurangnya pendidikan dan kemiskinan.

Maka dari permasalahan diatas penulis tertarik untuk meneliti tentang program yang dilakukan oleh Yayasan Berdaya Kreatif dalam membantu masayarakat khususnya para remaja yang memiliki latar belakang keluarga tidak mampu, korban terdampak banjir dan remaja yang berada di panti asuhan dalam memberikan pembelajaran tentang pendidikan umum dan pelatihan soft skill untuk membantu mereka merencakan apa yang menjadi keinginan mereka melalui program Akademi Berdaya.

Sejumlah penelitian terdahulu patut dipertimbangkan antara lain Perliando dkk. (2018). Pemberdayaan generasi muda dapat mengambil bentuk bidang kesenian. Pada kasus di Kelurahan Pampang, ada tiga tahap pemberdayaan yaitu tahap penyadaran, transformasi dan peningkatan, serta pendapat langsung dari generasi muda kelurahan budaya pampang. Wulandari, P.K. (2016), pemberdayaan dapat dilakukan pemerintah misalnya melalui Dinas Pariwisata, Pemuda, dan Olahraga (Disparpora)seperti di Kabupaten Trenggalek dalam bidang ekonomi kepariwisataan. Menurutnya pemberdayaan dilakukan dengan mengembangkan softskill pemuda sebelum diterjunkan ke lapangan dalam meningkatkan daya tarik wisata Trenggalek.

Kemudian El Hasanah, L.N. (2015), pemberdayaan dengan membidik para pemuda. Bahwa perkembangan ekonomi kreatif tidak dapat terlepas dari generasi muda sebagai gudang kreativitas. Generasi muda adalah sumber daya produktif yang dengan ide kreatifnya dapat membuka sebuah usaha (wirausaha) yang dapat membantu pemerintah dalam mengurangi tingkat pengangguran di angkatan kerja produktif. Semakin banyak anak muda yang berkecimpung di dunia wirausaha, semakin banyak pula produktivitas yang dihasilkan sehingga berdampak pula pada meningkatnya perkembangan ekonomi nasional.

Terkait dengan pemberdayaan berbasis masjid secara spesifik diteliti oleh Nurjamilah (2016). Hasil penelitian menunjukkan bahwa bentuk pemberdayaan 
yang dilakukan meliputi pemberdayaan dalam aspek spiritual, social, pendidikan, politik, ekonomi, dan pertahanan dengan cara menyediakan akses melalui pembangunan masjid, pasar sekitar masjid, dan melatih pasukan pertahanan.

Penelitian sejenis lainnya terkait dengan pemberdayaan diteliti oleh Widjajanti (2011). Hasilnya menunjukkan, ada dua pola cara peningkatan keberdayaan masyarakat, yaitu, pertama pola yang terdiri dari dua tahapan untuk keberdayaan, dan kedua pola yang menunjukkan bahwa untuk meningkatkan keberdayaan diperlukan tiga proses.

Perbedaan penelitian ini dengan penelitian terdahulu, penelitian ini menggunakan metode deskriptif dengan pendekatan kualitatif dengan fokus pada proses pemberdayaan yang berlangsung dan hasil atau manfaat yang dirasakan masyarakat dan khususnya kalangan remaja.

\section{HASIL DAN PEMBAHASAN}

Dalam kamus besar bahasa Indoneisa istilah akademi bermakna, lembaga pendidikan, yang tiga tahun kurang lebih lamanya, yang mendidik tenaga professional. Atau juga akademi bisa dikatakan sebagai perkumpulan orang yang dianggap arif, terkenal untuk meninggikan ilmu, kesustraan atau bahasa.

Berasal dari kata "didik" (memelihara), melatih (ajaran) untuk berakhlak baik dan berfikir positif (cerdas), sedangkan secara istilah pendidikan ialah semua usaha orang tua dalam berteman dengan anak-anak untuk membantu perkembangan jasmani dan rohaninya kearah kedewasaan. Dalam hal ini tentunya mempengaruhi pola pemikiran anak untuk lebih dewasa dalam memilih dan merencakan sesuatu. (Purwanto, 2002: 23)

Sedangkan tujuan pendidikan dalam pandangan Islam berhubungan dengan manusia yang berakhlak, yaitu menjadi hamba Allah yang mengandung terhadap kepercayaan dan penyerahan diri kepada-Nya. Pendidikan Islam tujuannya sama dengan upaya manusia dalam merealisasikan tujuan hidup manusia, yaitu bentuk penghambaannya secara penuh kepada Allah Swt.

Ada beberapa jenis pendidikan diantaranya: Pendidikan formal, nonformal juga informal. Pendidikan formal adalah pendidikan yang terstruktur dari bawah sampai tinggi. Pendidikan nonformal adalah pendidikan diluar pendidikan formal, seperti pendidikan di alam. Selanjutnya pendidikan informal adalah jalur pendidikan lingkungan dan keluarga.

Pemberdayaan ialah usaha membantu seseorang memperoleh daya dalam pengambilan keputusan serta melihat tindakan apa yang akan dilakukan. Yang dilakukan dengan memperoleh kemampuan dan rasa percaya diri untuk menggunakan daya atau kekuatan yang dimiliki, antara lain melalui kekuatan dari lingkungannya. Sedangkan menurut Shardlow pemberdayaan fokus membahas bagaimana seseorang dan kelompok berusaha mengontrol kehidupan dan 


\section{J. Al Afgani}

membentuk kehidupan di masa depan sesuai apa yang di inginkan oleh diri sendiri.

Menurut Sholeh (2014) lingkup kegiatan pemberdayaan ada dua, yaitu :Pertama, hal yang paling utama dalam memberdayakan masyarakat adalah diri sendiri, karena dari tujuan pemberdayaan itu sendir adalah untuk memperbaiki kehidpan maka yang harus diperbaiki terlebih dahulu adalah manusia itu sendiri.

Kedua, setelah melakukan bina manusia hal penting kedua adalaj bina usaha, karena respon masyarakat akan terfokus apabila ada peningkatan perokonomian juga, dalam hal lain peningkatan kesejateraan masyarakt di tuntut untuk dipenuhi dalam pembinaan atau pemberdayaan masyarakat.

Salah satu cara dalam pembinaan usaha atau ekonomi ini, menurut Safe'i adalah dengan celestial business (Bisnis surgawi) yang muncul akibat sesuatu yang dirampas dari masyarakat, bahwa dalam mengejar kebahagiaan diperlukan keseimbangan antara material dan spiritual. Karena pada saat ini terjadi kesenjangan yang mengakibatkan munculnya imprelialisme di satu sisi dan pemiskinan di sisi lainnya. Hal ini diakibatkan oleh fungsi ekonomi yang berubah menjadi alat untuk gaya hidup modern yang orientasinya untuk individu, bukan lagi sebagai alat untuk menyejahterakan masyarakat yang orientasinya sosial. Maka di pandang perlu adanya celestial business ini untuk mengedepankan nilainilai Illahi yang tertanan di dalamnya. (Safei, 2016:23)

Menyikapi hal itu bahwa dalam pembangunan perekonomian diperlukan adanya keseimbangan anatara material dan spiritual, dalam menunjang kesejahteraan ekonomi masyarakat. Karena pada hakikatnya ketika hati dan juga pikiran seimbang maka hasil yang di dapat adalah ketentraman, begitu pula dengan material (fisik) dan spiritual (batin) apabila seimbang maka yang menjadi akhir dari keduanya adalah kesejahteraan, yang diperoleh dari keuletan dan kesabaran dalam menjalaninya yang di ikutinya juga dengan melaksanakan perintah agama untuk membantu mewujudkan usaha yang adil dan halal.

Metode pemberdayaan akan lebih baik jika melibatkan masyarakat, karena dengan partisipasi masyarakat diharapkan kedepannya akan menjadi mandiri, metode tersebut adalah Metode penilaian keadaan secara cepat (Rapid Rural Appraisal), Metode penilaian secara partisipatif (Participatory rapid appraisal), Metode diskusi terarah (focus group discussion), Metode partisipasi pembelajaran dan praktik (Participatory learning and action), Metode sekolah lapangan, Metode pelatihan partisipatif. (Sholeh, 2014:34)

Kata remaja berasal dari adolescence (bahasa inggris) atau adolecere (bahasa latin) yang mempunyai arti tumbuh, menjadi dewasa. Adolecen maupun remaja menggambarkan seluruh perkembangan baik fisik, intelektual, emosi dan sosial. Remaja adalah masa peralihan di antara dari anak anak dan dewasa dimana anak memiliki pertumbuhan yang cepat di semua bidang yang dikehendaki. Sedangkan Basri menyatakan bahwa remaja merupakan mereka 
yang telah meninggalkan pribadi anak-anak yang ketergantungan menuju masa memiliki rasa tanggung jawab sendiri. (Basri, 1996:34)

Simpulan pendapat di atas, masa remaja adalah peralihan untuk menuju dewasa, bertumbuh fisik, mental, intelektual dan sosial dalam menunjang keinginannya serta rasa bertanggung jawab. Mendefinisikan remaja sebagai suatu masa dimana individu berkembang yang menunjukan tanda seksual sekundernya sampai saat ia mencapai kematangan. Juga pada masa remaja seseorang mengalami kemajuan psikologis dan pola identifikasi serta mengalami peralihan dari ketergatungan yang utuh ke keadaan lebih mandiri. (Sarwono, 2012:40)

Jadi sesuai pendapat di atas, yang dimaksud dengan remaja adalah fase dimana individu mulai berkembang yang ditandai dengan tanda seksual sekunder menuju tanda kematangan serta proses dimana terjadi peralihan masa kanakkanaknya menuju dewasa atau ke keadaan yang lebih mandiri.

Lokasi penelitian ini dilakukan di Yayasan Berdaya Kreatif yang berada di Jalan raya Samarang No. 35 Desa Langensari, Kecamatan Tarogong Kidul, Kabupaten Garut. Adapun penulis memilih lokasi tersebut

Penulis menumukan suatu hal yang menarik yang dapat dijadikan suatu peneltian dan pembelajaran bagi pelaku pemberdayaan. Penulis beranggapan bahwa penelitian yang dilakukan akan sesuai dengan potensi akademis, karena sangat berkaitan dengan proses pemberdayaan sumber daya manusia.

Temuan dari penelitian ini adalah proses pemberdayaan remaja di program akademi berdaya, metode dan program pemberdayaan remaja di program akademi berdaya.

\section{Proses Pemberdayaan Remaja di Program Akademi Berdaya}

Partisipasi pemberdayaan remaja di program akademi berdaya, dalam kegiatan pemberdayaan, Berdaya Kreatif tidak hanya berfokus pada pembinaan anakanak yatim dhuafa, tapi juga turut serta mengundang orang lain untuk ikut membantu proses pemberdayaan, mengajak menjadi relawan juga jadi kakak asuh bagi anak-anak yatim dhuafa.

Hal ini tentunya menjadi suatu pengalaman yang baik untuk semua orang yang ingin ikut dalam proses pemberdayaan, menghadirkan sesuatu yang baru untuk kepentingan diri dan kelompok sehingg diharapkan dapat saling tolong menolong dalam memberdayakan remaja. Secara lebih jelas partisipasi yang dilakukan oleh berdaya kreatif ini ada dua cara : Pertama, kerelawanan. Cara ini mengedepankan para penggiat pemberdayaan untuk ikut serta terjun kelapangan membantu mencari dan mengidentifikasi adik-adik yang mempunyai potensi untuk beradaya juga adik-adik yang di kategorikan yatim dhuafa, juga membantu dalam penghimpunan dana untuk sarana dan keberlangsungan program akademi berdaya. 


\section{J. Al Afgani}

Hal ini juga sesuai dengan apa yang di sampaikan oleh ketua program Akademi Berdaya Ibu Yini Fitriyamin, yang mengatakan :

"Iya mal, kita membuka atau merekrut orang-orang untuk ikut memberdayakan remaja, dimana nantinya para relawan ini diharapkan bisa mengambil pengalaman yang nantinya bisa diterapkan oleh mereka di lingkungannya, tapi mal, tidak hanya sebatas itu fungsi relawan disini juga diharapkan dapat membantu dalam tahap penghimpunan agaran kegiatan program, karena dengan adanya relawan cakupan untuk menarik orang lain dalam mengikuti program ini menjadi banyak". (Hasil wawancara, Juli 2018)

Kedua, kakak asuh. Dalam program Akademi Berdaya ini kakak asuh berperan sangat penting karena fungsi dan juga salah satu tujuan di adakannya kakak asuh adalah untuk menjadi salah satu donator atau yang membiayai satu anak untuk satu periode pendidikan. Menurut Kang Agung Gumlear Sebagai Presiden direktur mengatakan :

"Kakak asuh ini mempunyai peran yang vital di program akber (akademi berdaya), karena tanpa mereka kegiatan akademi berdaya ini akan sedikit tersendat, mereka (kakak asuh) secara sukarela menyumbangkan sedikit hartanya, dengan alasan yang sederhana, yakni ingin melihat senyum dan tatapan masa depan yang lebih cerah bagi anak-anak yatim dhuafa". (Hasil wawancara, Juli 2018).

Hal ini membuktikan bahwa dalam memberdayakan remaja, yayasan Berdaya Kreatif juga mengutamakan untuk memberi pengalaman bagi siapa saja untuk ikut membantu membahagiakan yatim dhuafa. Dalam mencari kakak asuh ini juga di bantu oleh para relawan yang ikut menyebarkan beberapa poster ajakan untuk bergabung bersama Yayasan Berdaya Kreatif dalam memberdayakan penerus bangsa.

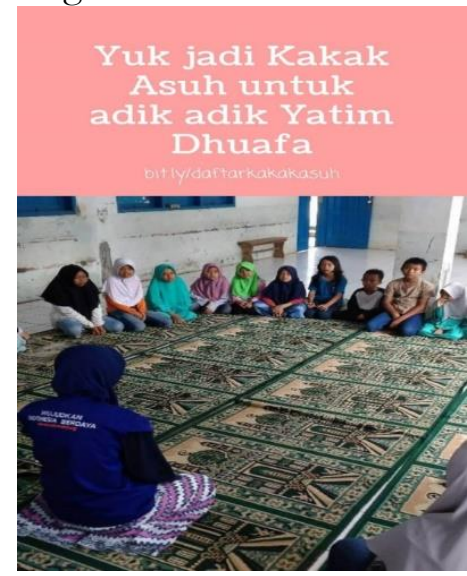

Gambar 1.

Poster ajakan menjadi kakak asuh 
(Sumber : arsip Yayasan Berdaya Kreatif)

Bentuk ajakan itulah yang berhasil menarik beberapa kakak asuh untuk ikut membantu dalam proses pemberdayaan yang di lakukan oleh Yayasan Berdaya Kreatif melalui program Akademi Berdaya. Menurut Ibu Yini Fitriyamin sebagai ketua Program Akademi Berdaya mengatakan :

"Kakak asuh ini memiliki pilihan tersendiri untuk mendonasikan hartanya, kami menyediakan beberapa paket donasi untuk tiap bulan pembinaan di mulai dari Rp. 250.000 sampai dengan Rp. 600.000, - per bulannya. Beberapa kakak asuh ini cakupannya luas mal, tidak hanya dari Garut saja bahkan yang paling jauh ada yang dari Jeddah Arab Saudi, tapi masih warga Indonesia namun bermukim disana”. (Hasil wawancara, Juli 2018).

Dari hasil wawancara tersebut dapat di simpulkan bahwa kakak asuh ini mempunyai peran yang sangat penting bagi keberlangsungan program Akademi berdaya. Serta ajakan menyeluruh yang dilakukan oleh Yayasan Berdaya Kreatif ini memungkinkan setiap orang untuk beramal dan ikut memberdayakan para remaja yatim dhuafa.

Alur terjadi pemberdayaan remaja di program akademi berdaya. Program ini berawal dari komunitas pemberdayaan pada tahun 2013, dimana kegiatan yang pada saat itu di haruskan untuk turun langsung ke pedesaan dan berinteraksi dengan anak-anak desa. Kemudian muncullah sebuah perasaan yang ingin memberikan manfaat dengan memberdayakan adik-adik yatim dhuafa. Kemudian dalam hal lain yayasan ini juga secara langsung mengunjungi beberapa panti asuhan yang ada di Garut dan belum mendapati panti asuhan yang memiliki program kemandirian dan entrepreneurship. Menurut Aji Imam selaku Vice Presdir Yayasan Berdaya Kreatif mengatakan :

"Sampai saat ini program kami ada di Sembilan desa di Kabupaten Garut, Jawa Barat, kami juga telah berkunjung ke 12 panti asuhan dan ada tiga panti asuhan yang menjadi binaan kami salah satunya Al-Amin, serta pelaksanaan program di sembillan kecamatan terdampak banjir bandang (tahun 2016) di Kabupaten Garut. Alhamdulillah. ucap syukur kami pada saat ini, bisa membantu anak-anak yatim dhuafa dan mengembalikan semangat mereka untuk beraktifitas dan menatap masa depan". (Hasil wawancara, Juli 2018).

Dalam proses pemberdayaan ini ada beberapa alur yang perlu di penuhi untuk menjadi bagian dari anak-anak yang mendapat kesempatan dalam pembinaan dan pelatihan, beberapa alur tersebut : rekrutmen, peminatan, martikulasi, pembinaan, kompetensi lulusan. 


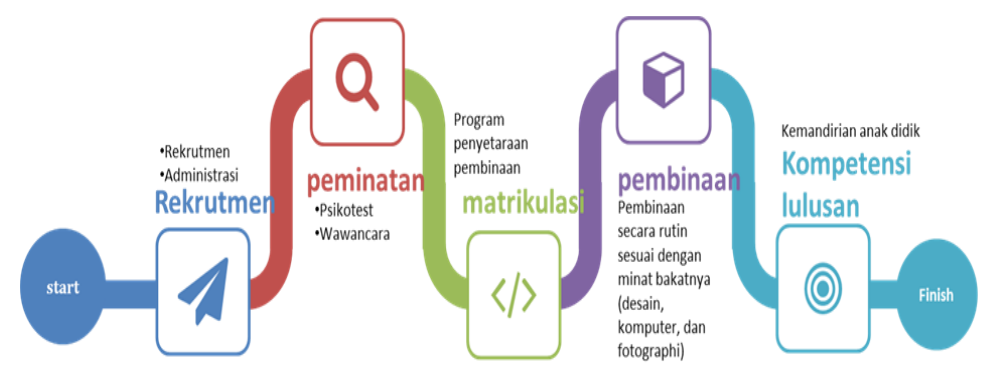

Gambar 2.

Alur terjadinya pemberdayaan

(Sumber : Hasil Penelitian, Juli 2018)

Sasaran pemberdayaan remaja di program akademi berdaya.Dalam wawancara yang dilakukan kepada Ibu Yini selaku ketua program Akademi berdaya bahwa :

"Untuk fokus utama kita sebenarnya ke Yatim dhuafa yang berada di desa binaan dan panti asuhan yang kita bina". (Hasil wawancara, Juli 2018).

Dari hasil wawancara diatas bahwa sasaran dari pemberdayaan yang di lakukan oleh Yayasan Berdaya Kreatif melalui program akademi berdaya ini adalah : Pertama, yatim dhuafa meliputi desa binaan dan Panti Asuhan. Kedua, lingkungan sekitar. Ketika melakukan pemberdayaan yang paling penting adalah ingat tempat atau lokasi dimana kita memberdayakan, karena ini lah factor penting untuk mendukung keberlangsungan dan kelancaran program.

Hal inilah yang dilakukan oleh Yayasan Berdaya Kreatif melalui program akademi berdaya, yang membantu masyarakat sekitar untuk ikut dalam kegiatan pemberdayaan, bahkan sampai membantu beberapa anak warga disana untuk menjadi peserta kegiatan pemberdayaan. Dan hal ini pula di sambut baik oleh Bapak Budi selaku ketua RW 10 desa Langensari yang mengatakan :

"Ya Alhamdulillah jang, ku ayana yayasan Berdaya Kreatif ieu, marulangkalih anu aya didie tiasa ngiringan kana kagiatan anu positif, bapa oge sok ameng ka rumah berdaya ngobrol sareng kang raha teras sareng peserta akber (akademi berdaya), yen leres pisan kagiatan didie the positif, janten warga anu sanes oge teu aya cariosan anu awon naha sok rame wae di bumi eta, da tos tarerangen ayana barudak anu di latih sareng di pasihan pamadegan kangge mandiri”. (Hasil wawancara, Juli 2018).

Mengajak warga untuk ikut membantu pemberdayan serta memberikan kesempatan untuk warga menjadi bagian dari kegiatan pemberdayaan.

Dan untuk menarik minat para peserta yang nantinya akan di bina yayasan ini juga mengajak orang lain untuk menyebarkan poster pengrekrutan peseta akademi berdaya. 


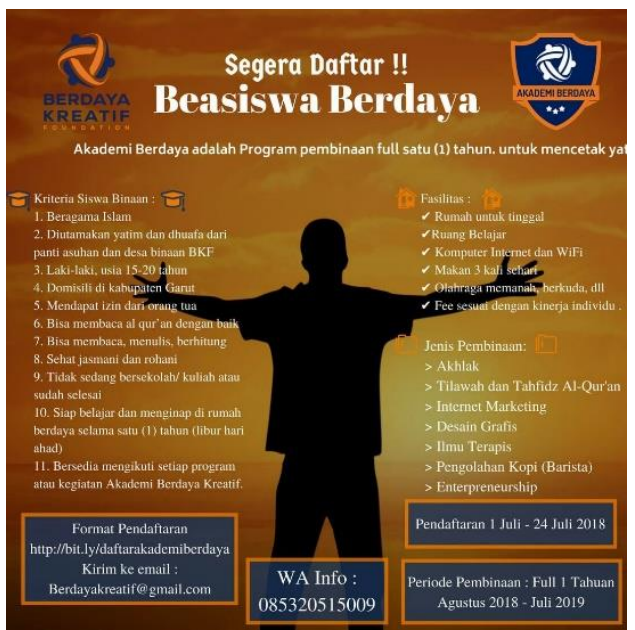

Gambar 3.

Poster rekrutmen peserta akademi berdaya

(Sumber : arsip Yayasan Berdaya Kreatif)

Remaja pada saat ini sudah mulai melupakan jati dirinya, terbukti dengan banyak beredarnya remaja yang lebih mementingkan pengikut dalam suatu media sosial dengan melakukan tindakan bodoh. Hal ini terjadi karena remaja merupakan masa peralihan di antara masa anak-anak dan masa dewasa di mana anak-anak mengalami pertumbuhan cepat di segala bidang. Masa peralihan ini lah yang akan menjadikan remaja melihat bagaimana dirinya ketika dewasa nanti, perkembangan remaja hari ini cenderung terlalu cepat, sehingga ada pemendekan masa muda menuju dewasa khususnya di belahan bumi selatan. Tyska berpendapat bahwa anak muda di dunia Barat sedang mengalami perpanjangan masa muda karena anak-anak muda sekarang cenderung menghabiskan waktu yang lebih lama untuk mengenyam pendidikan formal, memiliki pekerjaan paruh waktu, dan masih tergantung pada orang tua. Di sisi lain, anak muda di belahan bumi selatan mengalami periode masa muda yang diperpendek karena banyak yang harus menjadi pekerja anak, terkurung dalam kemiskinan dan memiliki kesempatan pendidikan yang terbatas. Mengindikasikan bahwa kekurangan dalam hal pendidikan dapat membuat seseorang lebih cepat dewasa dan membuang masa muda nya.(Faturochman, 2012: 119-120)

Masa remaja adalah peralihan untuk menuju dewasa, bertumbuh fisik, mental, intelektual dan sosial dalam menunjang keinginannya serta rasa bertanggung jawab. Mendefinisikan remaja sebagai suatu masa dimana individu berkembang yang menunjukan tanda seksual sekundernya sampai saat ia mencapai kematangan. Juga pada masa remaja seseorang mengalami kemajuan psikologis dan pola identifikasi serta mengalami peralihan dari ketergatungan yang utuh ke keadaan lebih mandiri (Sarwono, 2012:40). 


\section{J. Al Afgani \\ Metode dan Program Pemberdayaan Remaja di Program Akademi Berdaya}

Metode pemberdayaan remaja di program akademi berdaya. Dalam program ini metode yang di gunakan oleh yayasan Berdaya Kreatif untuk pemberdayaan remaja adalah pembelajaran dan pelatihan (praktik), tentunya hal ini yang melatarbelakangi tercapainya tujuan dari program akademi berdaya, lebih jelasnya tentang pemberian metode pemberdayaan ini : Pertama, Teori. Proses yang dilakukan ketika memberikan teori kepada adik-adik peserta akademi berdaya berkenaan langsung dengan tujuan dan dari tujuan inilah melahirkan kurikulum sebagai landasan untuk para pengajar dan juga capaian adik-adik akademi berdaya, kurikulum yang di berikan:kurikulum berakhlak, kurikulum berkemandirian, kurikulum berketerampilan.

Dari kurikulum diatas para peserta akademi berdaya di harapkan mampu untuk bisa menguasainya dalam periode satu tahun pembelajaran. Hal ini sesuai dengan apa yang dikatakan oleh ibu Yini selaku ketua program akademi berdaya mengatakan :

"Kita punya target untuk anak-anak agar mempunyai karakter atau akhlaq yang sesuai dengan Al-Quran, kemudian juga untuk menjadikan mereka terampil dalam berbagai aspek pembelajaran sesuai kurikulum dan terakhir diharapkan mereka bisa lebih mandiri. Ini juga berkaitan langsung dengan target kita di awal bahwa dalam menarik minat anak-anak yatim dhuafa, kita menerapkan semua kurikulum yang bisa dibilang tidak ada di sekolah manapun kecuali ekstrakuriler mereka, nah disini secara langsung di pelajari oleh mereka, sehingga mereka nantinya mempunyai pengetahuan tentang beberapa keterampilan". (Hasil wawancara, Juli 2018).

Pernyataan diatas mempertegas tentang metode pembelajaran yang diberikan untuk menunjang keberehasilan anak dalam menjadikan mereka menjadi pribadi yang berkarakter dan berdaya.

Kedua, praktik lapangan. Kegiatan ini berkaitan langsung dengan melaksanakan tugas untuk anak-anak agar mendapatkan pengalaman ketika nanti di masyarakat. Dalam metode ini yayasan melalui program akademi berdaya memberikan teori sekaligus langsung praktiknya. Berkaitan dan hal itu ibu Yini mengatakan :

“... iya mal, kita memang dalam pembelajaran lebih mengedepankan praktik dari pada teori sehingga, ketika belajar harus selalu ada praktik, yang memungkinkan nantinya anak-anak jadi terbiasa untuk melakukannya". (Hasil wawancara, Juli 2018)

Melalui pernyaataan diatas dapat diambil simpulan bahwa metode pemberdayaan akademi berdaya lebih mengedepankan aspek praktik untuk memberikan pengalaman secara langsung bagi anak-anak. Praktik yang dilakukan secara langsung oleh anak-anak akademi berdaya adalah :Pertama, Hafalan Qur'an 
, Adik-adik ini rutin menghafal Qur'an setiap hari senin, selasa, jumat dan sabtu.

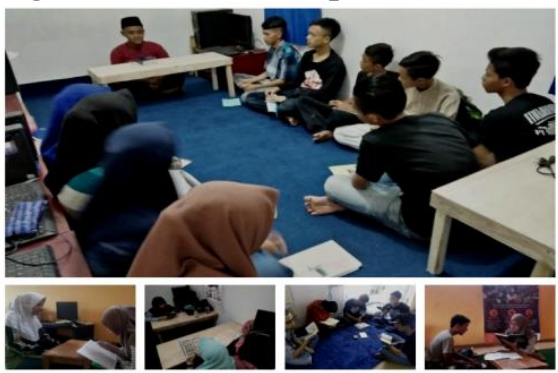

Gambar 4.

Proses menghafal Al-Quran

(Sumber: hasil dokumentasi, Juni-Juli 2018)

Bimbingan Konseling, adik-adik akademi berdaya secara langsung berkonsultasi dengan para mentornya, terkait cita-cita mereka :

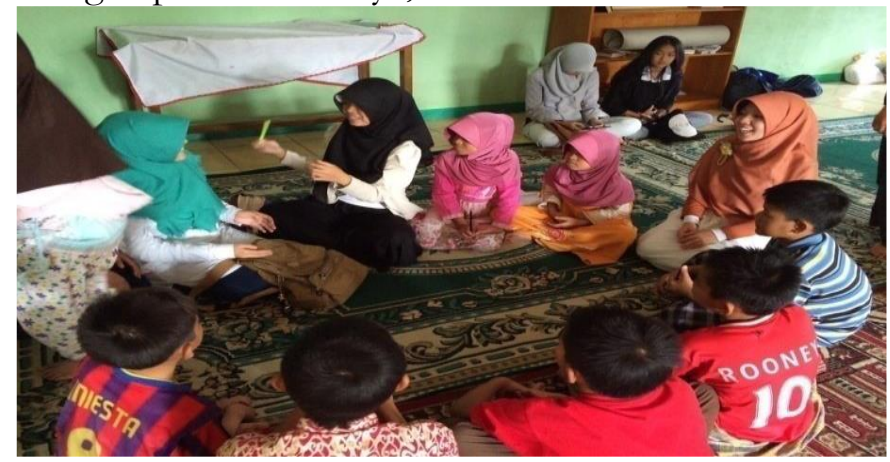

\section{Gambar 5.}

Bimbingan konseling

(Sumber : hasil dokumentasi : Juni 2018)

Program Ekstrakurikuler nya yaitu memanah rutin seminggu sekali dan berkuda menyesuaikan dengan waktu. 


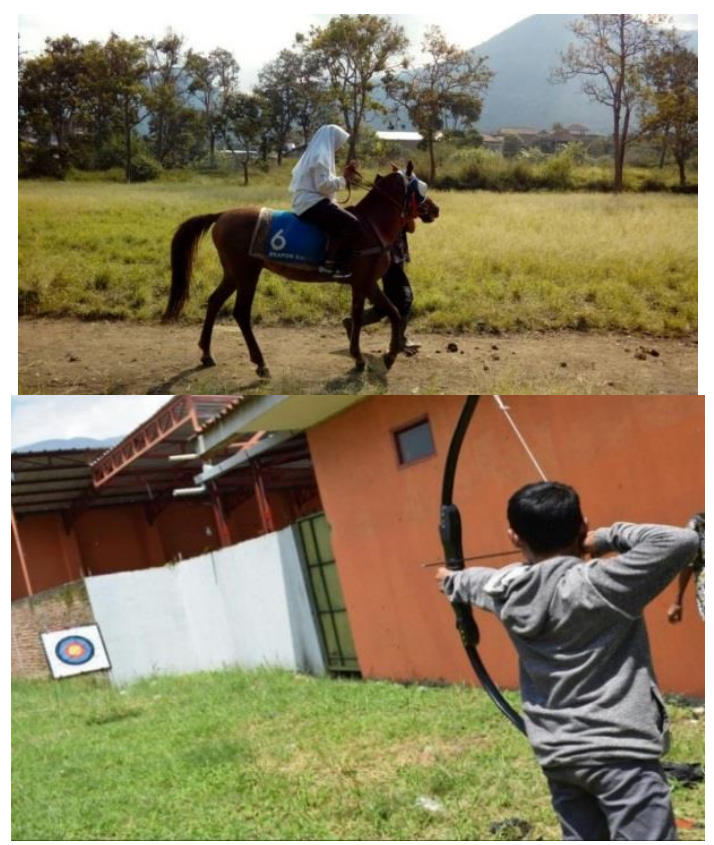

Gambar 6.

Memanah dan berkuda

(Sumber : Hasil dokumentasi, Juli 2018)

Pelatihan Internet Marketing sedang berlangsung dengan waktu pembinaan 5 pertemuan dalam seminggu. Adik-adik dilatih belajar design di corel, template website, bikin artikel di blog, hingga belajar membuat olshop. Hal ini bertujuan agar nanti kedepannya anak-anak mampu mengoprasikan berbagai keterampilan design, Karena seiring berjalannya waktu kebanyakan pekerjaan agar berhubungan langsung dengan dunia maya dan dunia grafis.

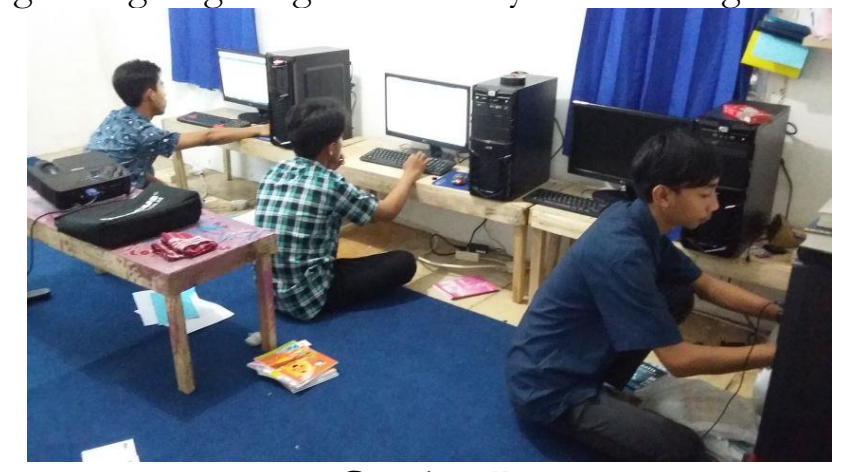

\section{Gambar 7.}

Pembelajaran internet marketing dan design grafis

(Sumber : hasil dokumentasi : Juli 2018)

Pelatihan Fotografi dan Videografi setiap hari senin, kamis dan jumat. 


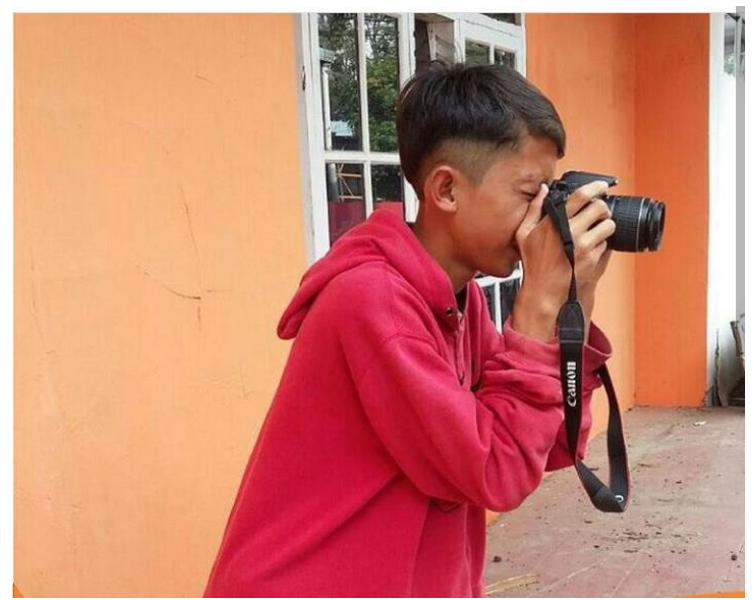

Gambar 8.

Fotografi

(Sumber : hasil dokumentasi, Juli 2018)

Program pemberdayaan di akademi berdaya.Akademi berdaya merupakan program yang di dalamnya terdapat tujuan yang harus di capai, cara dalam mendapatkan atau mencapai tujuan tersebut adalah dengan memberikan tahapan-tahapan yang memberikan jalan guna mencapai tujuan, tahapan tersebut merupakan sebuah turunan dari program akademi berdaya yang secara mendalam membahas bagaimana program tersebut bisa membantu mewujudkan tujuan dari akademi berdaya. Menurut ibu Yini mengatakan :

"Memang dari awal tujuan kita tidak akan pernah berubah mal, kenapa ada visi, misi dan tujuan, itu semua sebuah langkah awal untuk mencapai kesuksesan kegiatan akademi berdaya tersebut, makanya mal, dalam mencapai tujuan akademi berdaya, ada beberapa cara atau program di dalamnya yakni ada akademi berdaya ramadhan, akademi berdaya keterampilan, dan terakhir ada akademi berdaya pesantren internet marketing (PIM)". (Hasil wawancara, Juli 2018).

Dari pernyataan di atas ada hal yang menjadikan program akademi berdaya sukses dengan menjalankan tahapan atau cara memperoleh tujuan akademi berdaya, antara lain :

Akademi berdaya Ramadhan. Pada program ini sebagaimana tujuan dari akademi berdaya yakni mencetak generasi yang berahklaq, maka akademi berdaya ramadhan menjadi pilihan atau solusi untuk mencapai tujuan tersebut di dalamnya ada kegiatan sesuai dengan kurikulum ahklaq yakni beberapa dari itu adalah belajar mengenai sejarah Islam dan tahfidz.

Akademi berdaya pesantren internet marketing (PIM). Pada program ini peserta akademi berdaya di haruskan untuk tinggal atau menetap di yayasan, karena memang salah satu tujuan dari program ini adalah melatih kemandirian 


\section{J. Al Afgani}

ketika jauh dari orangtua. Dalam program ini juga anak-anak dilatih untuk menambah wawasan tentang dunia maya tentunya dalam hal positif, beberpa kegiatan diantaranya adalah melatih anak-anak akademi berdaya untuk membuat blog yang kemudian di isi dengan konten tulisan dan pengalaman pribadi mereka, atau wawasan baru yang mereka dapatkan di tuangkan dalam tulisan dan menjadi materi pengajaran.

Sebenarnya, tidak hanya hal-hal diatas yang dilakukan oleh peserta akademi berdaya pesantren internet marketing (PIM) ini karena memang tujuan utamanya melatih keterampilan, ahklaq dan kemandirian, maka kegiatan lainnya adalah mengaji, mengkaji kitab kuning, tahfidz, keterampilan desain dan yang lainnya. Menurut Diki dan Yana selaku peserta akademi berdaya mengatakan :

"BKF (Berdaya Kreatif Foundation) bagi kami seakan keluarga kedua. Kami tinggal disana kemudian banyak pelajaran yang dapat kami ambil sehingga kami bisa tersenyum di kemudian hari. Di BKF, kami menaruh mimpi yang akan kami wujudkan. Berdaya Kreatif Foundation is the best for us". (Hasil wawancara, Juli 2018)

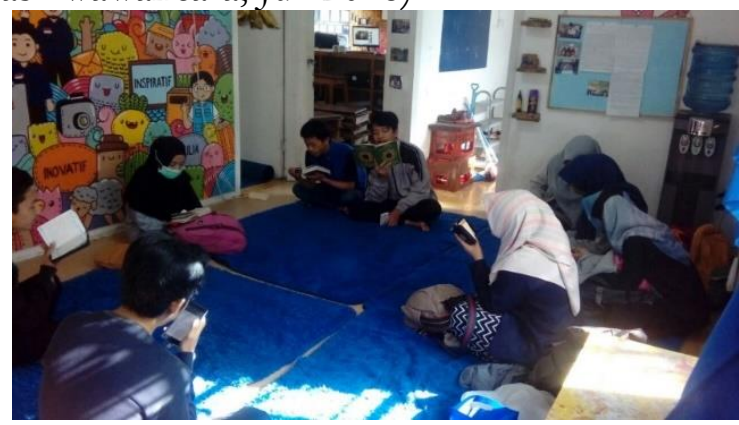

Gambar 9.

Keseharian dalam pembelajaran dan pemberdayaan.

(Sumber : Hasil Dokumentasi, Juli 2018)

Pada program ini para peserta akademi berdaya akan di bina dan dilatih sesuai dengan minat dan bakat mereka selama satu tahun, karena dalam pemberian materi peserta pada program ini diberi cukup materi yang padat dan dilatih kedisiplinannya dalam bertanggung jawab. Selama satu tahun ini juga peserta masih bisa untuk pulang ke rumah mereka namun kewajiban sebagai peserta harus tetap di lakukan.

Perkembangan karakter merupakan pengembangan yang bertahap dalam membentuk sikap, mental dan akhlak. Membangun karakter adalah proses mengukir jiwa, sehingga terbentuk jiwa yang unik, menarik dan lain daripada yang lain. Dalam perkembangan karakter ini hal yang akan menjadi factor utama adalah lingkungan, pengalaman dan bimbingan dari pendidik. Tentunya dengan terbentuknya karakter yang positif dapat membantu para remaja dalam mensejahterakan diri yang nantinya dapat direalisasikan pada kehidupan untuk 
bertahan hidup dan bersikap tenang dalam menyelesaikan permasalahan yang ada. (Faturochman, 2012: 138)

Metode pemberdayaan akan lebih baik jika melibatkan masyarakat, karena dengan partisipasi masyarakat diharapkan kedepannya akan menjadi mandiri, metode tersebut adalah Metode penilaian keadaan secara cepat (Rapid Rural Appraisal), Metode penilaian secara partisipatif (Participatory rapid appraisal), Metode diskusi terarah (focus group discussion), Metode partisipasi pembelajaran dan praktik (Participatory learning and action), Metode sekolah lapangan, Metode pelatihan partisipatif (Sholeh, 2014:34).

\section{Gerakan Pemberdayaan Remaja di Program Akademi Berdaya}

Penguatan kapasitas dan kualitas pemberdaya. Sebagai sebuah lembaga pemberdayaan yayasan Berdaya Kreatif bergerak dengan kerelawan dan pengorbanan untuk memberdayakan masyarakat, menciptakan iklim positif bagi semua relawan untuk bisa sama-sama memberdayakan lingkungannya.

Dalam memberdayakan perlu bagi seorang pemberdaya melihat atau mengetahui sedikitnya tentang apa itu pemberdayaan dan berbagai proses, metode yang di gunakan dalam pemberdayaan, menurut Agung Gumelar Presiden Direktur Yayasan Berdaya Kreatif :

“... Iya benar bahwa dalam memberdayakan kami juga perlu penguatan kualitas dan kapasitas di berbagai sector pemberdayaan, makanya kami suka mengadakan atau membuka rekrutmen anggota baru untuk menjadi relawan di yayasan, tidak hanya itu kami juga sering mengadakan upgrade terhadap para relawan dan pengurus di yayasan, hal ini dilakukan dalam bentuk kepedulian kami bahwa dalam memberdayakan jangan melupakan diri sendiri dulu yang perlu di berdayakan, karena dari pengalaman pribadi yang dapat meyakinkan ketika akan melakukan pemberdayaan". (Hasil wawancara, Juli 2018)

Dari pernyataan di atas, bahwa yayasan berdaya kreatif juga melakukan upgrading untuk para relawan dan pengurus. Hal ini di lakukan untuk meningkatkan kualitas para relawan dan pengurus dalam pemberdayaan diri dan nantinya di aplikasikan di lingkungannya atau tempat yang pada saat itu di tempati para relawan. 


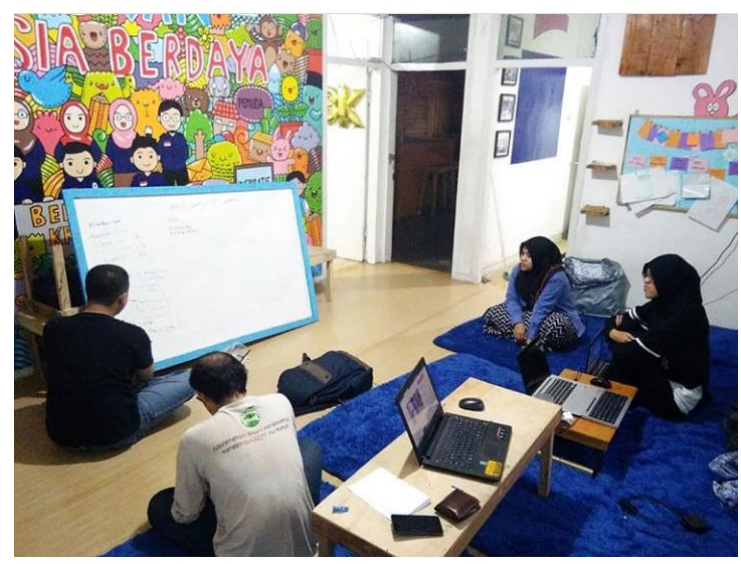

\section{Gambar 10.}

(Sumber : hasil dokumentasi, Juli 2018)

Para relawan dan juga pengurus nantinya juga dapat mengisi di program akademi berdaya sebagai bentuk realisasi dari proses upgrading, Menurut Yini :

“... untuk tenaga pengajar di akademi berdaya, kita memanfaatkan relawan yang ada di yayasan, karena sebelum mencari keluar mengapa tidak untuk memanfaatkan yang ada dulu, sekiranya juga kakak asuh yang menjadi dalah satu donator kerap mengisi materi untuk adik-adik binaanya, tapi kami juga kadang mengundang beberapa orang atau ahli dalam bidang yang di kuasainya untuk menyampaikan materi di akademi berdaya". (Hasil wawancara, Juli 2018)

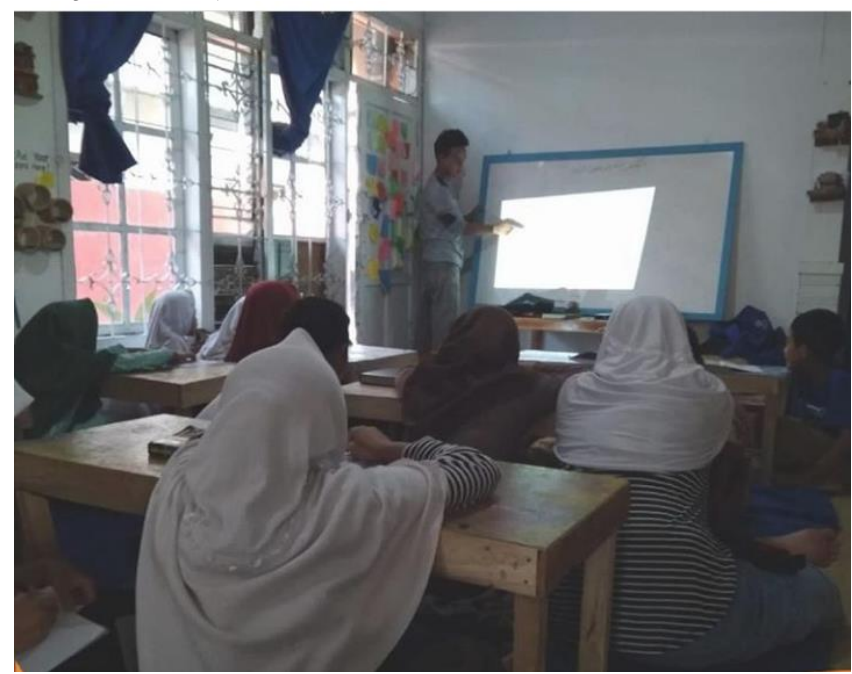

Gambar 11.

Kegiatan Upgrading

(Sumber : Hasil dokumentasi, Juli 2018) 
Hal inilah yang menunjukan adanya siklus saling bekerjasama untuk melakukan pemberdayaan. Kakak asuh juga ikut memantau kegiatan dari adikadiknya dalam memperoleh pengalaman dan pembelajaran yang diberikan oleh akademi berdaya. Menurut kak Faiz, salah satu kakak asuh dari program akademi berdaya mengatakan :

“... benar kang, di akademi berdaya ini kami sebagai kakak asuh tidak hanya sebatan memberi bantuan dalam bentuk santunan tapi kami juga di beri keleluasaan untuk mengontrol dan melihat bagaimana proses perkembangan adik-adik yang di bina disana", (Hasil wawancara, Juli 2018).

Dari sebuah kerelawanan dan keinginan yayasan ini mampu menggerakan dan mengajak orang lain untuk ikut dalam pemberdayaan, sehingga orang lain yang tertarik bisa ikut dan turun secara langsung dalam program pemberdayaan. Yang mana hal ini berkaitan langsung dengan peningkatan kualitas dan kapasitas yayasan Berdaya Kreatif ini.

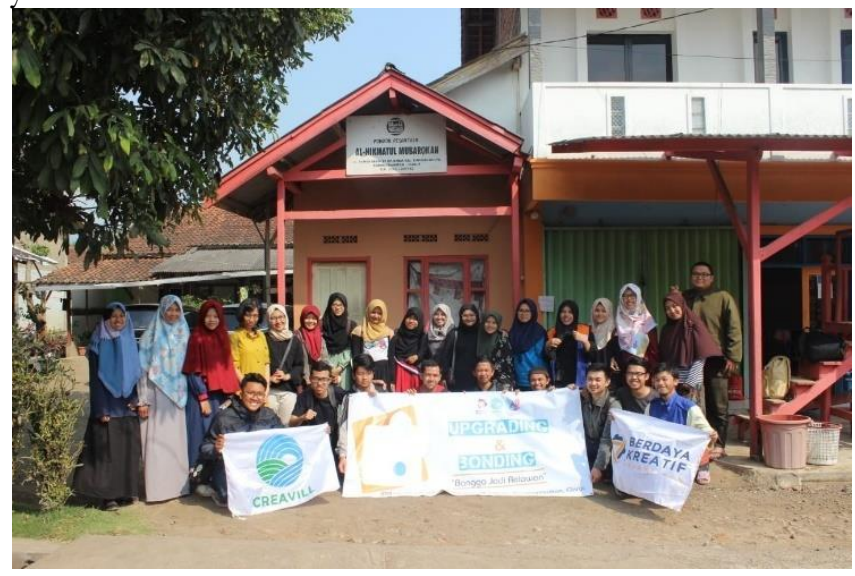

Gambar 12.

(Hasil Dokumentasi, Juli 2018)

Kegiatan setalah Upgrading

Tingkat keberdayaan pengurus (progres dan regres).Untuk melihat tingkat keberdayaan sebenarnya adalah hal sulit, karena sejatinya orang yang berdaya hanya bisa di ketahui dari pendapat orang lain, yang memperhatikan dan melihat perkembangan, sehingga unsur keberdayaannya akan tampak dengan sendirinya.

Tapi dalam beberapa hal yang menjadikan orang berdaya adalah dengan keinginannya untuk berubah, dan bukan atas paksaan atau iming-iming hadiah, menurut Aji Imam Muflih sebagai wakil direktrut Yayasan Berdaya Kreatif menyebutkan :

"Orang berdaya adalah ketika orang tersebut mampu mandiri dan memenuhi kebutuhannya sendiri”. (Hasil wawancara, Juli 2018). 


\section{J. Al Afgani}

Dari pendapat diatas dapat dipahami sebagai suatu keinginan orang untuk merubah apa yang menjadi kebutuhannya dan mereka berusaha untuk mendapatkannya dengan perubahan tersebut. Ketika mereka memperlihatkan keberanian dan menutupi segala kekurang yang mereka miliki untuk perubahan yang lebih baik.

Tabel 1.

Pemberdayaan yang dilakukan pengurus di lingkunganya

\begin{tabular}{|c|c|c|c|}
\hline No & Nama & Jabatan & $\begin{array}{l}\text { Pemberdayaan yang } \\
\text { dilakukan }\end{array}$ \\
\hline 1. & Agung Gumelar & Presiden Direktur & $\begin{array}{l}\text { Pemberdayaan SDA, SDL } \\
\text { dan SDE. } \\
\text { Peningkatakan yang di } \\
\text { lakukan adalah dengan } \\
\text { memberikan pelatihan dan } \\
\text { mengajak masarakat sekitar } \\
\text { untuk menemukan solusi } \\
\text { untuk permasalah juga } \\
\text { pemanfaatan potensi dari } \\
\text { masyarakat dan } \\
\text { lingkungannya. }\end{array}$ \\
\hline 2. & Aji Imam Muflih & Vice Presdir & $\begin{array}{l}\text { Pemberdayaan Ekonomi, } \\
\text { dalam bentuk mengajak } \\
\text { tetangga untuk ikut } \\
\text { membantu dalam } \\
\text { berwirausaha. }\end{array}$ \\
\hline 3. & Evi Lutfiah & $\begin{array}{l}\text { Direktur Berdaya } \\
\text { Konsultan }\end{array}$ & $\begin{array}{l}\text { Mengajak untuk peduli } \\
\text { terhadap lingkungan dan } \\
\text { membuang smapah pada } \\
\text { tempatnya. }\end{array}$ \\
\hline 4. & Rosalin Qurota Ayunin & $\begin{array}{l}\text { Direktur Marekting } \\
\text { dan Fundraising }\end{array}$ & $\begin{array}{l}\text { Mengajak keluarga terjun } \\
\text { langsung ke lapangan untuk } \\
\text { melihat bagaiman kondisi } \\
\text { masyarakat yang kurang } \\
\text { mampu dan mencoba untuk } \\
\text { bersama-sama membina dan } \\
\text { memberdayakan mereka. }\end{array}$ \\
\hline 5. & Windi Ariesti & $\begin{array}{l}\text { Marketing } \\
\text { Fundraising }\end{array}$ & $\begin{array}{l}\text { Peningkatan sumber daya } \\
\text { manusia. Dengan mengajak } \\
\text { untuk sering membaca dan } \\
\text { membuat rumah baca di } \\
\text { lingkungan tempat tinggal. }\end{array}$ \\
\hline 6. & M. Iqbal Mujahid Akbar & $\begin{array}{l}\text { Direktur Berdaya } \\
\text { Core }\end{array}$ & $\begin{array}{l}\text { Peningkatan sumber daya } \\
\text { manusia, mencoba } \\
\text { memberikan pemahaman } \\
\text { tentang agama, dan membatu } \\
\text { dalam hal penyusunan }\end{array}$ \\
\hline
\end{tabular}




\begin{tabular}{|c|c|c|c|}
\hline & & & $\begin{array}{l}\text { konsep untuk proses } \\
\text { pemberdayaan selanjutnya, } \\
\text { seperti pengaktifan kembali } \\
\text { karang tuna sebagai metode } \\
\text { untuk pemberdayaan. }\end{array}$ \\
\hline 7. & Yini Fitriyamin & $\begin{array}{l}\text { Direktur Berdaya } \\
\text { Edu }\end{array}$ & $\begin{array}{l}\text { Peningkatan sumber daya } \\
\text { manusia. Peningkatan } \\
\text { kualitas belajar anak dan } \\
\text { membina juga mengajarkan } \\
\text { segala hal untuk merubah } \\
\text { masa depan, dengan } \\
\text { memberikan pelatihan dan } \\
\text { pendirian rumah baca. }\end{array}$ \\
\hline 8. & Irma Rahayuna & $\begin{array}{l}\text { Direktur Berdaya } \\
\text { Socent }\end{array}$ & $\begin{array}{l}\text { Di lingkungan keluarga } \\
\text { dengan mengajak untuk } \\
\text { membentuk kelompok usaha, } \\
\text { dalam membantu kehidupan } \\
\text { keluarga dan masyarakat } \\
\text { sekitar. }\end{array}$ \\
\hline 9. & Dina Marlina & $\begin{array}{l}\text { Direktur Berdaya } \\
\text { Care }\end{array}$ & $\begin{array}{l}\text { Mengajak tetangga sekitar } \\
\text { untuk hidup sehat dan } \\
\text { menjaga lingkungannya, } \\
\text { sebagai upaya } \\
\text { memberdayakan kepedulian } \\
\text { masyarakat. }\end{array}$ \\
\hline
\end{tabular}

(Sumber : Hasil Penelitan wawancara, Juli 2018)

Dari tabel di atas untuk mengukur tingkat keberdayaan pengurus dapat dilihat dari keinginan untuk memberdayakan orang lain, seperti dilingkungannya sendiri, kebebasan yang dimiliki untuk menyuarakan pendapat dan ikut dalam mengambil suatu keputusan merupakan idikator keberdayaan. Sehingga, bisa di katakan bahwa pengurus di Yayasan Berdaya Kreatif sudah berdaya, karena mampu untuk memberikan sesuatu manfaat bagi orang lain dan mampu mengakomodir apa yang di butuhkan oleh diri sendiri.

Kerjasama pemberdayaan remaja. Selain upgrading lembaga, maka dalam memberdayakan masyarakat di perlukan pula kerjasama dengan berbagai bidang yang perlunya ada kerjasama agar, tidak adanya suatu program yang sama dengan lembaga lain di lain waktu yang berbeda, karena itu kerjasam ini di perlukan dalam pemberdayaan. Salah satu panti asuhan di Garut yakni Al-Amin adalah salah satu panti yang bekerjasama dengan akademi berdaya dalam memberdayakan remaja. Menurut Ibu Aam pengurus panti Al Amin mengatakan

"Alhamdulillah a, ku ayana akademi berdaya, ibu asa kabantosan kangge ngurus barudak di panti, mugia tiasa salajengna we aya kerjasama sareng akademi berdaya supados tiasa ngabantosan panti, oge panti ngabantosan program akademi berdaya". (Hasil wawancara, Juli 2018).

Dalam kegiatannya saling membantu merupakan cara untuk saling 


\section{J. Al Afgani}

mengakrabkan dan memperoleh kepercayaan, karena dengan meraih kepercayaan dari berbagai komunitas, lembaga dan masyarakat itu dapat memperlama kegiatan pemberdayaan dan kemudian akan mendapat bantuan dari luar dalam proses pemberdayaan nya.

Dalam bekerjasama juga harus ada beberapa syarat yang perlu untuk di penuhi sebagai bentuk kerja professional, ini juga yang diterapkan oleh yayasan berdaya kreatif untuk mengajak setiap lembaga, komunitas dan pemerintah dalam memberdayakan masyarakat, beberapa syarat kerjasama yang tidak memberatkan salah satu pihak adalah tujuan dari yayasan Berdaya Kreatif, tentunya untuk masalah kontrak kerja itu menjadi rahasia lembaga itu sendiri, tapi menurut Rosalin Qurota Ayunin menyebutkan bahwa :

“... iya bentuk dan perjanjian kerjasama itu menjadi bagian dari rahasia yang hanya diketahui oleh para pemimpin lembaga dan anggotanya, karena ini berkaitan dengan apa saja yang bisa menyebabkan kemunduran salah satu lembaga, tapi yang penting dari bentuk kerjasama ini adalah samasama menyelesaikan program, dan yang menjadi tujuan utamanya adalah percaya satu sama lain untuk menunjang keberhasilan program dan lembaga". (Hasil wawancara, Juli 2018)

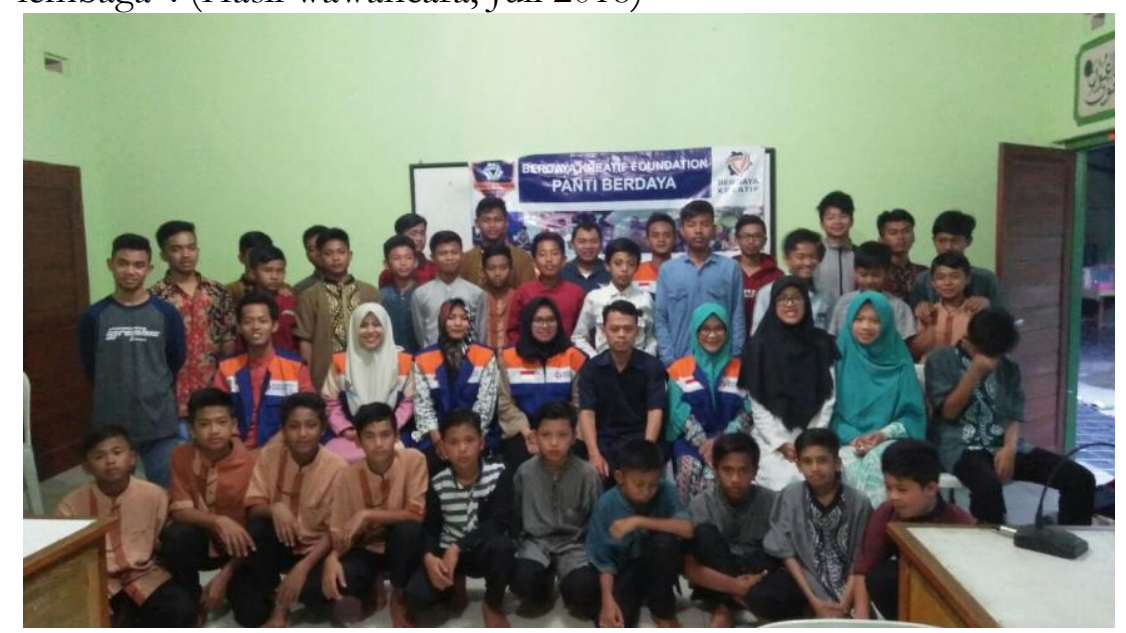

Gambar 13.

Proses mengajak kerjasama di salah satu panti

(Sumber : Hasil dokumentasi, Juli 2018)

Akademimemiliki fokus utamanya adalah peningkatan sumber daya manusia (SDM) dalam arti lain adalah kemampuan dari daya pikir dan fisik yang dimiliki seseorang. Perilaku dan sifatnya dibentuk oleh lingkungan dan keturunanya, kemudian prestasi kerjanya di motivasi oleh keinginan untuk memenuhi apa yang di inginkannya (Muhaemin, 2017).

Pendidikan ialah semua usaha orang tua dalam berteman dengan anak- 
anak untuk membantu perkembangan jasmani dan rohaninya kearah kedewasaan. Dalam hal ini tentunya mempengaruhi pola pemikiran anak untuk lebih dewasa dalam memilih dan merencakan sesuatu. (Purwanto, 2002:23)

\section{PENUTUP}

Berdasarkan hasil penelitian yang telah dilaksanakan di Yayasan Berdaya Kreatif Desa Langensari Kabupaten Garut mengenai pemberdayaan remaja melalui program akademi berdaya, maka dapat disimpulkan sebagai berikut :Pertama, proses pemberdayaan remaja melalui program akademi berdaya dimulai dengan mengajak semua orang untuk ikut membantu dalam menjalankan program ini, terbukti dengan adanya relawan mengajar dan kakak asuh, yang tidak hanya sebagai donator tapi juga ikut dalam pemberian materi pemberdayaan sehingga mereka mengerti bahwa memang telah terjadi pemberdayaan yang dilakukan oleh Yayasan Berdaya Kreatif.

Kedua, metode dan program dalam pemberdayaan remaja melalui program akademi berdaya, penggunaan metode yang dilakukan oleh Yayasan Berdaya Kreatif dalam program akademi berdaya adalah pembelajaran dan praktik, dengan memberikan teori atau kurikulum pendidikan yang membahas tentang berakhlaq, berketerampilan dan kemandirian yang selanjutnya diberikan praktik langsung kelapangan yang di harapkan dapat beradaptasi dengan kondisi lapangan atau mendapatkan pengalaman yang nyata di masyarakat. Dengan berbagai program yang mendukung dalam menjalankan akademi berdaya adalah adanya akademi berdaya Ramadhan, akademi berdaya keterapilan dan akademi berdaya pesantren internet marketing yang memiliki kurikulum berbeda dan jangka waktu satu bulan sampai satu tahun masa pembelajaran dan praktik.

Ketiga, gerakan dalam pemberdayaan remaja melalui program akademi berdaya adalah pembinaan dan peningkatan kualitas dari lembaga, juga para relawan dan kakak asuh dalam proses memberdayakan, kemudian pada progresnya nanti tidak hanya ikut memberdayakan di yayasan saja tapi juga mulai membuka pemberdayaan di sekitar lingkungan tempat tinggalnya, terbukti dengan para pengurus yang sudah mulai melakukan pemberdayaan di lingkungannya sendiri dimulai dari keluarga sampai masyarakat sekitar, atau pada regresnya kembali pada keadaan biasanya yang hanya ikut-ikut saja, yang disebabkan karena niat yang setengah-setengah (ragu) juga tidak munculnya keinginan untuk ikut berkontribusi di masyarakat. Selanjutnya hal penting dalam pemberdayaan adalah kerjasama dengan berbagai pihak yang sesuai dengan program pemberdayaan yang dilakukan.

Berdasarkan hasil penelitian dan simpulan yang telah dikemukakan, penulis menyampaikan saran sebagai berikut :Pertama, kepada pemerintah. Perlunya keterlibatan pemerintah untuk membantu masyarakat, khususnya masyarakat 


\section{J. Al Afgani}

Garut dalam proses pemberdayaan remaja, sehingga diharapkan nantinya para generasi penerus dapat lebih berdaya atau mampu dalam memaksimalkan potensi dalam dirinya dan tidak terjerumus pada hal negatif, dengan kerelawan dan kedermawanan Garut bisa menjadi kota Intan yang sesungguhnya. Serta perlunya untuk bekerjasama dengan berbagai penggiat pemberdayaan yang ada di Kabupaten Garut.

Kedua, untuk Peniliti Selanjutnya. Masih banyak hal yang perlu tementemen dalami di Yayasan Berdaya Kreatif terutama dalam pemberdayaan yang dilakukan pada desa-desa yang ada di Garut serta pemberdayaan perekonomian masyarakat melalui kegiatan pengembangan produk berbasis potensi yang ada di sekitar masyarakat serta gerakan pada bidang kesehatan masyarakatnya.

\section{DAFTAR PUSTAKA}

Basri, H. (1996). Remaja Berkualitas: Problematika Remaja dan Solusinya. Yogyakarta: Pustaka Pelajar

El Hasanah, L.N. (2015). Pengembangan Wirausaha Muda Ekonomi Kreatif Berbasis Budaya di Daerah Istimewa Yogyakarta. JURNAL STUDI PEMUDA, 4 ( 2) , 268-280.

Faturochman, dkk. (2012). Psikologi untuk Kesejabteraan Masyarakat, Yogyakarta : diterbitkan atas kerjasama Fakultas Psikologi UGM dengan Pustaka Pelajar.

Muhaemin, E. (2017). Dakwah Digital Akademisi Dakwah. Ilmu Dakwah: Academic Journal for Homiletic Studies, 11(2), 341-356.

Nurjamilah, C (2016) Pemberdayaan Masyarakat Berbasis Masjid dalam Perspektif Dakwah Nabi SAW, Journal of Islamic Studies and Humanities, 1 (1): 93-119.

Perliando dkk. (2018). Pemberdayaan Generasi Muda dalam Melestarikan Kesenian Dayak di Kelurahan Budaya Pampang Kota Samarinda. eJournal Ilmu Pemerintahan , 6 (1), 425-438.

Purwanto, N. (2002). Imu Pendidikan Teoritis dan Praktis. Bandung: PT Remaja Rosdakarya.

Safei, A. A. (2016). Sosiologi Dakwah: Rekonsepsi, Revitalisasi, dan Inovasi. Yogyakarta: Deepublish (Grup CV Budi Utama)

Sarwono, S. W. (2012). Psikologi Remaja. Jakarta: PT Raja Grafindo Persada.

Sholeh, C. (2014). Dialetika Pembangunan dan Pemberdayaan. Bandung : Fokusmedia.

Widjajanti, K. (2011) Model Pembedayaan Masyarakat, Jurnal Ekonomi Pembangunan, 12 (1): 15-27. 
Wulandari, P.K. (2016).Generasi Sadar Wisata (Pemberdayaan Pemuda dan Pendidikan Duta Wisata di Kabupaten Trenggalek). JSPH Jurnal Sosiologi Pendidikan Humanis, 1(2), 140 - 148. 